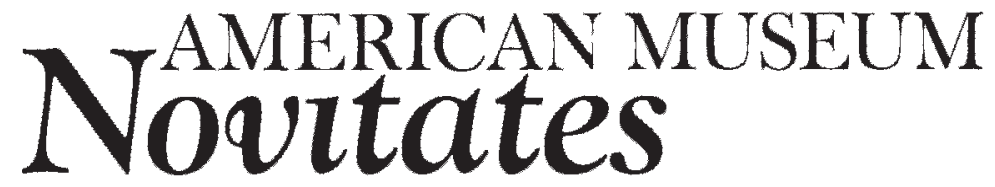

PUBLISHED BY THE AMERICAN MUSEUM OF NATURAL HISTORY CENTRAL PARK WEST AT 79TH STREET, NEW YORK, NY 10024 Number 3611, 17 pp., 7 figures, 1 table

April 9, 2008

\title{
An Unusual, Primitive Piesmatidae (Insecta: Heteroptera) in Cretaceous Amber from Myanmar (Burma)
}

\author{
DAVID A. GRIMALDI ${ }^{1}$ AND MICHAEL S. ENGEL ${ }^{2}$
}

\begin{abstract}
Cretopiesma suukyiae, new genus and species, is described, based on a unique female specimen in mid-Cretaceous (c. 100 myo) amber from northern Myanmar. Features of C. suukyiae unique for the small Recent family Piesmatidae include a long, protrudent clypeus, a dorsal carina of the head, lack of "jugal" lobes/appendices, widely separated coxae, very large scutellum, and the venation of the corium; some of these are plesiomorphic and shared with Aradidae. C. suukyiae possesses the cuticular areolation and propleural cavities distinctive to Piesmatidae. Phylogenetic analysis of Recent and fossil genera of piesmatids resulted in a cladogram with Cretopiesma as sister group to the remainder of the family. Relationships of this unusual species and of Piesmatidae within Pentatomomorpha are discussed.
\end{abstract}

\section{INTRODUCTION}

The Piesmatidae is a small family of approximately 40 Recent species and three genera, which are rather small in size (generally 2-4 mm long) and have extensive areolation of the head, thorax, and corium of the hemelytra. The distinctive microsculpture initially led hemipterists to classify these bugs within or near the cimicomorphan family
Tingidae (see the historical reviews by Drake and Davis, 1958; Heiss and Péricart, 1983). Not until the work of Tullgren (1918), Leston et al. (1954), and Drake and Davis (1958) was the position of the family within the Pentatomomorpha established, though relationships within this infraorder are still obscure. Piesmatids have been considered to have an isolated position in the Pentatomomorpha (Stys, 1967), to be within the "malcid line"

\footnotetext{
${ }^{1}$ Division of Invertebrate Zoology (Entomology), American Museum of Natural History (grimaldi@amnh.org).

${ }^{2}$ Division of Invertebrate Zoology (Entomology), American Museum of Natural History; Division of Entomology (Paleoentomology), Natural History Museum, and Department of Ecology \& Evolutionary Biology, 1501 Crestline Drive - Suite 140, University of Kansas, Lawrence, Kansas 66049-2811 (msengel@ku.edu).
} 
(Malcidae, Colobathristidae, Berytidae) of the Lygaeoidea (Schaefer, 1972, 1981), or closely related to the rare, coleopteriform lygaeoids, the Psamminae (Henry, 1997). Later we will discuss the evidence for family-level relationships of the Piesmatidae, in light of the primitive new fossil we describe here. Major works on the family are the following: Drake and Davis (1958) on the morphology, an overview of genera, and treatment of the American species; Heiss and Péricart (1983), also on morphology, but also with detailed information on life histories, development, and the Palaearctic species; Narisu (2000) on a review of their biology; and two papers by Schaefer $(1972,1981)$ on relationships.

The Recent genera are Piesma Lepeletier de Saint Fargeau and Audinet-Serville, Miespa Drake, and Mcateella Drake. The rare Asian genus Thaicoris Kormilev was originally (Kormilev, 1969) and later (e.g., Schaefer, 1972, 1981) placed in the Piesmatidae, but it has recently been shown to belong to the Thaumastocoridae (Heiss and Popov, 2002). Piesma is the largest genus with approximately 31 species, and is largely Holarctic but with some African species. One common Western Hemisphere species, Piesma cinereum (Say), extends from North America into tropical regions of Central and South America. Péricart (1974) classified the genus into three subgenera, but most recently Heiss and Péricart (1997) elevated two of these (Afropiesma Péricart and Parapiesma Péricart) to generic rank. Miespa is a monotypic genus known only from Chile; Mcateella contains four described species from Australia, although numerous undescribed species exist (G. Cassis, personal commun., 2006). Thus, the family is essentially bipolar, occupying mostly the temperate regions of the northern and southern hemispheres.

Host plants of the few piesmatid species where feeding habits are known have been reviewed by Schaefer (1981). The Chenopodiaceae is the family that is most commonly exploited as hosts, species of which are common in salt marshes (the family also includes beets and spinach). Some species in the family Caryophyllaceae ("pinks," including carnations) are also common hosts. The widespread species Piesma cinereum is known to feed on three genera of chenopods, an amaranth (Amaranthus), and even a sedge (Cyperaceae). Several species feed on Acacia (Leguminosae), which are $P$. linnavouri Štys in Africa, and Mcateella in Australia. The hosts of Miespa are unknown.

Until now only two fossil species have been known. Heissiana serafini Popov in Eocene Baltic amber is considered to be closely related to the two small austral genera (Popov, 2001). Eopiesma trimerus Nel, Waller and De Ploëg, in lowermost Eocene (Sparnacian-aged) amber from the Paris basin is considered to be the sister group to all other piesmatids including Heissiana (Nel et al., 2004). Thus, the fossil we report here is only the third one documented for this interesting family of true bugs, and it extends the known geological age of the family to approximately twice what was known.

\section{Materials And Methods}

Burmese amber derives from the northern province of Kachin, near Myitkyina. The specimen reported here was specifically derived with thousands of other pieces from near the villages of Huangpa and Tanai, collected by R. Cruickshank of Leeward Capital Corp. (reviewed in Grimaldi et al., 2002). Age of the amber is estimated to be Cenomanian to Late Albian. The Cenomanian age (ca. 98 mya) is based on the geological occurrence of 21 Mesozoic insect taxa that occur as inclusions in Burmese amber (Grimaldi et al., 2002). The Albian age (ca. 105-100 mya) is based on one ammonite specimen and a modest sample of spores from one site (Cruickshank and Ko, 2003). Thus, a reasonable estimate of the age of Burmese amber is approximately 100 myo. The piece of amber was prepared according to the protocols described in Nascimbene and Silverstein (2000). Critical observation of the minute specimen (body length $1.45 \mathrm{~mm}$ ) required high resolution and magnification to view features such as scent glands, trichobothria, etc. Reflected fiber optic illumination was used to study the specimen at $144 \times$ with a Leitz Wetzlar stereoscope and also with a Zeiss compound scope at magnifications from 100 to $400 \times$. We examined two specimens of Heissiana serafini Popov (nos. GPIH 4490, and paratype GPIH 2208), loaned to us by Dr. 
Wolfgang Weitschat of the GeologischPaläontologisches Institut und Museum at the University of Hamburg. This allowed us to score several characters not mentioned in the original description of that species.

\section{SYSTEMATICS}

Family Piesmatidae Amyot and Audinet-Serville, 1843

Piesmides Amyot and Audinet-Serville, 1843: 300. Type genus: Piesma Lepeletier de Saint-Fargeau and Audinet-Serville, 1825.

Zosmenidae Dorhn, 1859: 41. Type genus: Zosmenus Laporte, 1833.

Diagnosis: Small (2-4 $\mathrm{mm}$ in length) pentatomomorphan bugs, some without trichomorphan synapomorphies. Integument and corium densely areolate-punctate. Head roughly transverse; compound eyes positioned posteriorly, roughly contiguous with pronotum; ocelli present in macropterous forms, absent in brachypterous and submacropterous forms; "jugal" appendices/lobes present and elongate (primitively absent in Cretopiesma); four antennomeres; mandibular plates strongly produced, reaching apex of clypeus in modern genera (unknown for Tertiary genera, not produced in Cretopiesma); labium foursegmented; bucculae present at base of rostrum. Pronotum subquadrate and explanate, with distinct longitudinal carinae (absent in the Eocene genus Eopiesma), without collar, calli distinct; propleura with distinct cavities beneath paranota; prosternum with depression for reception of rostrum. Mesoscutellum greatly exposed and generally small except primitively greatly enlarged in Cretopiesma; mesosternum with depression for reception of rostrum except in Miespa and Cretopiesma. Metapleural scent gland ostiole present (primitively so in Cretopiesma) or vestigial (all other genera). Hemelytral corium areolate; membrane reduced, nearly absent, or present with three or four nebulous veins and no cells; venation of corium (when present or discernable) variable. Hing wing (when present) with Sc absent; $\mathrm{R}$ and $\mathrm{M}$ separated distally. Legs unarmed; coxae close together, except widely separated in Cretopiesma; coxal cavities open; tarsi dimerous (trimerous in Eopiesma); pretarsus with paired, leaflike pseudopulvilli (i.e., arising from unguitractor plate, not the claws). Abdomen of nymphs and adults with dorsal abdominal glands on terga 3-4 or 4-5 (glands remain functional in adults); spiracles $2-6$ in dorsal position (pair 6 sometimes in submarginal position); sternum V and VI with trichobothria anterior to spiracle, except absent or very highly reduced in Miespa, Mcateella, and Cretopiesma (and perhaps also Heissiana and Eopiesma); female sternum VII completely divided into hemisternites; ovipositor lanceolate; second gonocoxopodites in inverted $\mathrm{U}$ position; spermatheca median, unpaired; male genitalia symmetrical.

\section{Cretopiesma, new genus}

Diagnosis: Distinguished from all other genera of piesmatids, Recent and extinct, by the following features: clypeus long, protruding, with a prominent median carina that extends to middle of frons; lack of "jugal" appendices/lobes; rostrum about as long as head, inserted far from clypeal apex, enclosed by bucculae at base; pronotum with pair of paramedian carinae, posterior margin slightly concave; mesoscutellum very large (length $0.21 \times$ the body length); coxae of each pair widely separated; corium venation distinctive, where veins $\mathrm{Sc}, \mathrm{R}+\mathrm{M}$, and $\mathrm{Cu}$ are not fused in a vein that runs parallel and proximal to the margin of the membrane and corium, instead with two transverse veins; membrane without "sutural area".

TyPe SPECIES: Cretopiesma suukyiae, new species.

Etymology: From Piesma, the type genus of the family; and from the Latin creta, meaning "white earth" or "chalk", which refers to deep, chalky deposits in England that originally defined the Cretaceous Period (145-65 mya).

\section{Cretopiesma suukyiae, new species}

Figures 1-3

Piesmatidae sp.: Grimaldi et al., 2002: 41, fig. 25e.

Diagnosis: As for the genus (see above).

Description: Based on unique female specimen; small, body flattened, length 


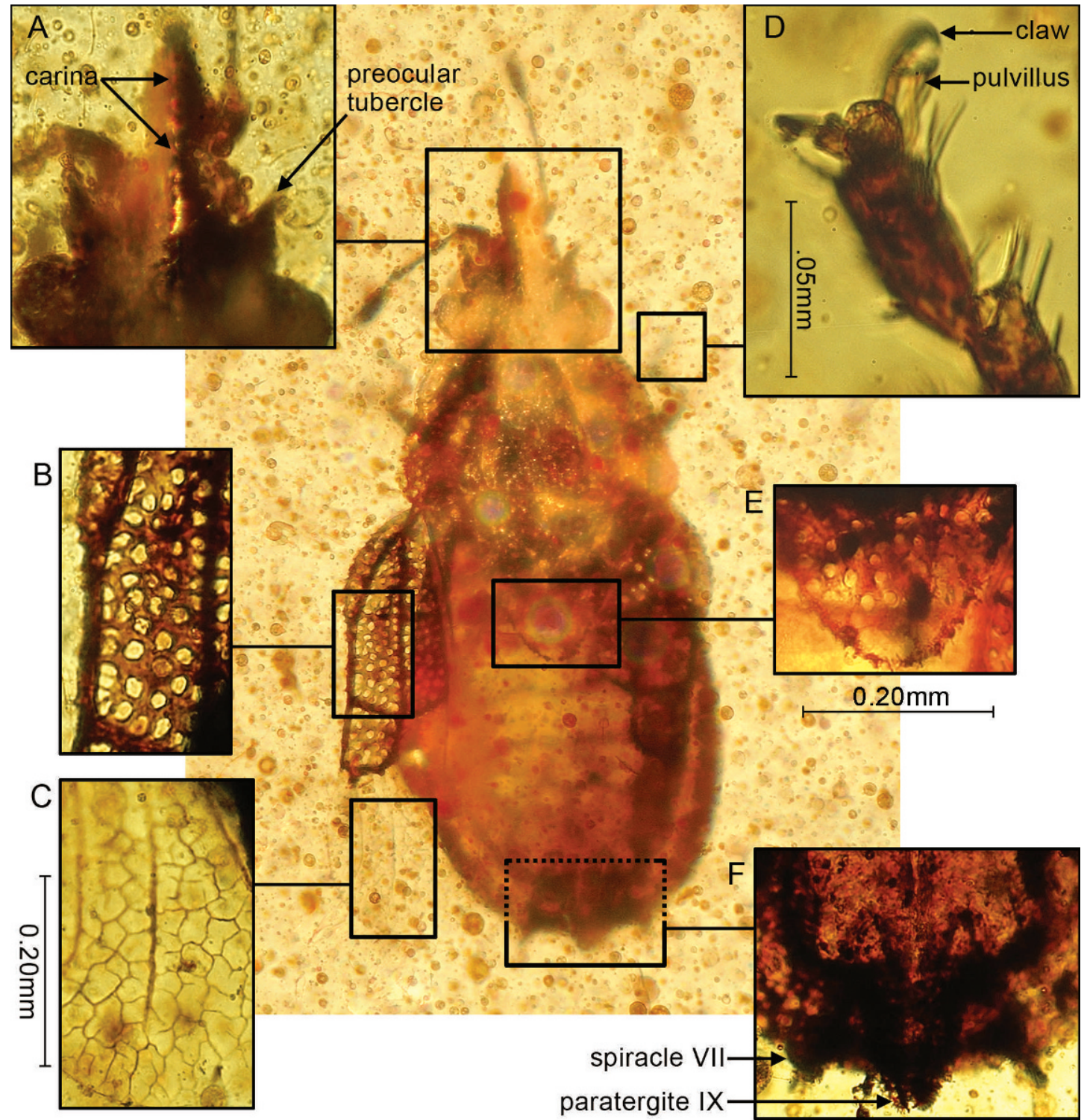

Fig. 1. Photomicrographs of holotype (AMNH Bu958) of Cretopiesma suukyiae, new genus and species, with dorsal habitus in center. A. Head, dorsal view. B. Detail of corium. C. Detail of wing membrane. D. Protarsus. E. Tip of scutellum. F. Terminalia, ventral view. A, B, C, E, F to same scale.

$1.45 \mathrm{~mm}$. Head: Wide, inserted into prothorax up to ventral margin of eyes; dorsally areolate; prognathous. Eyes extremely convex, bare of setulae; width across eyes $0.36 \mathrm{~mm}$. Ocelli absent, typical of submacropterous forms. Clypeus long, protrudent, tip extended to level of middle of 3rd antennomere. Clypeus with median carina, extending from tip to middle of frons. Jugal appendices absent. Ventral sur- face of head areolate. Bucculae short, extended from approximately middle of clypeus to anterior margin of preocular tubercles. Pair of large, conical preocular tubercles present, tips extend nearly to distal end of first antennomere. Antenna with four antennomeres; two basal antennomeres short and wide, relative lengths: (1) 1.0: (2) 1.1: (3) 2.9: (4) 1.5. Antennomere 3 long and thin, antennomere 


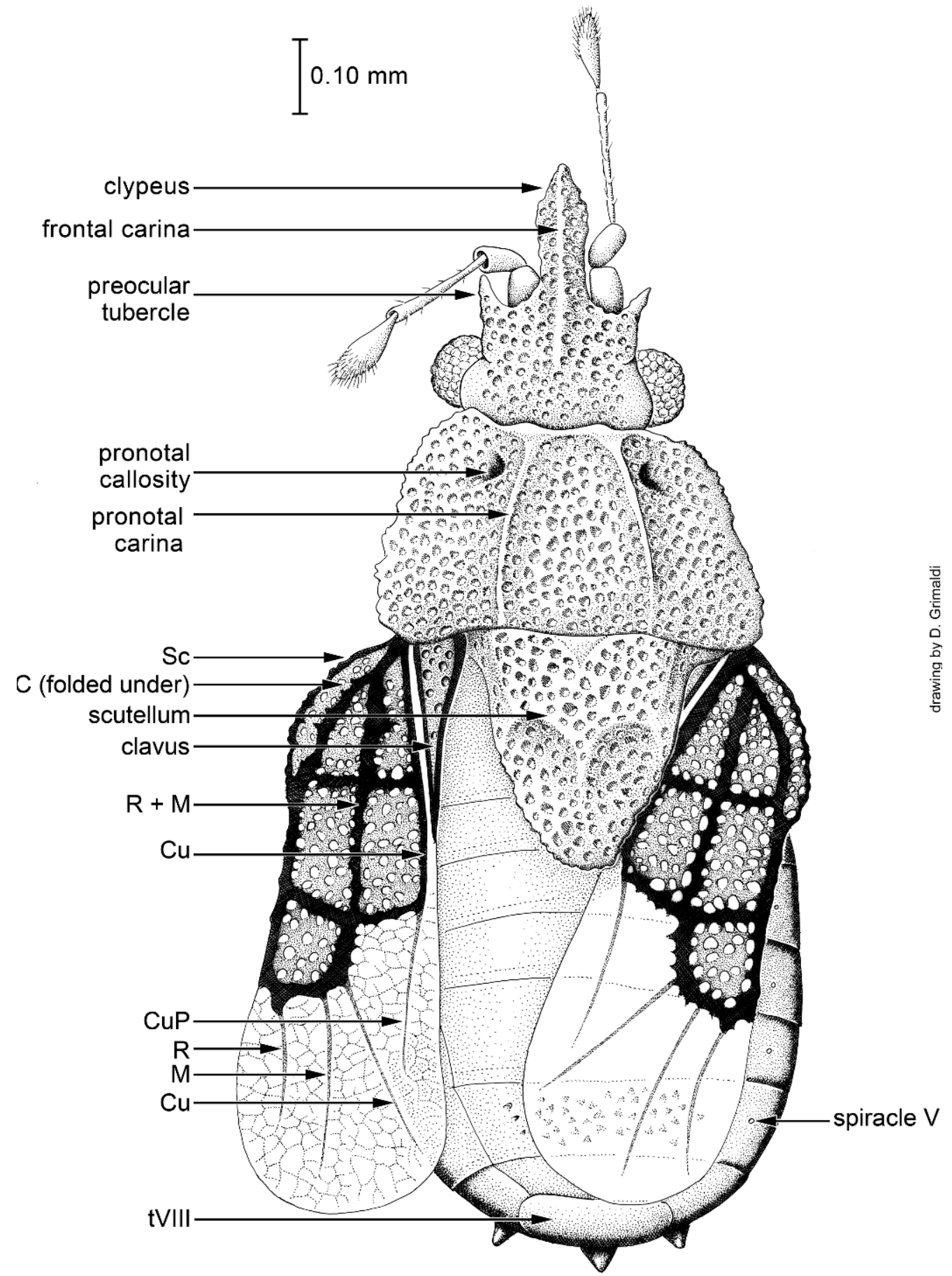

Fig. 2. Dorsal habitus of holotype of Cretopiesma suukyiae, new genus and species. 


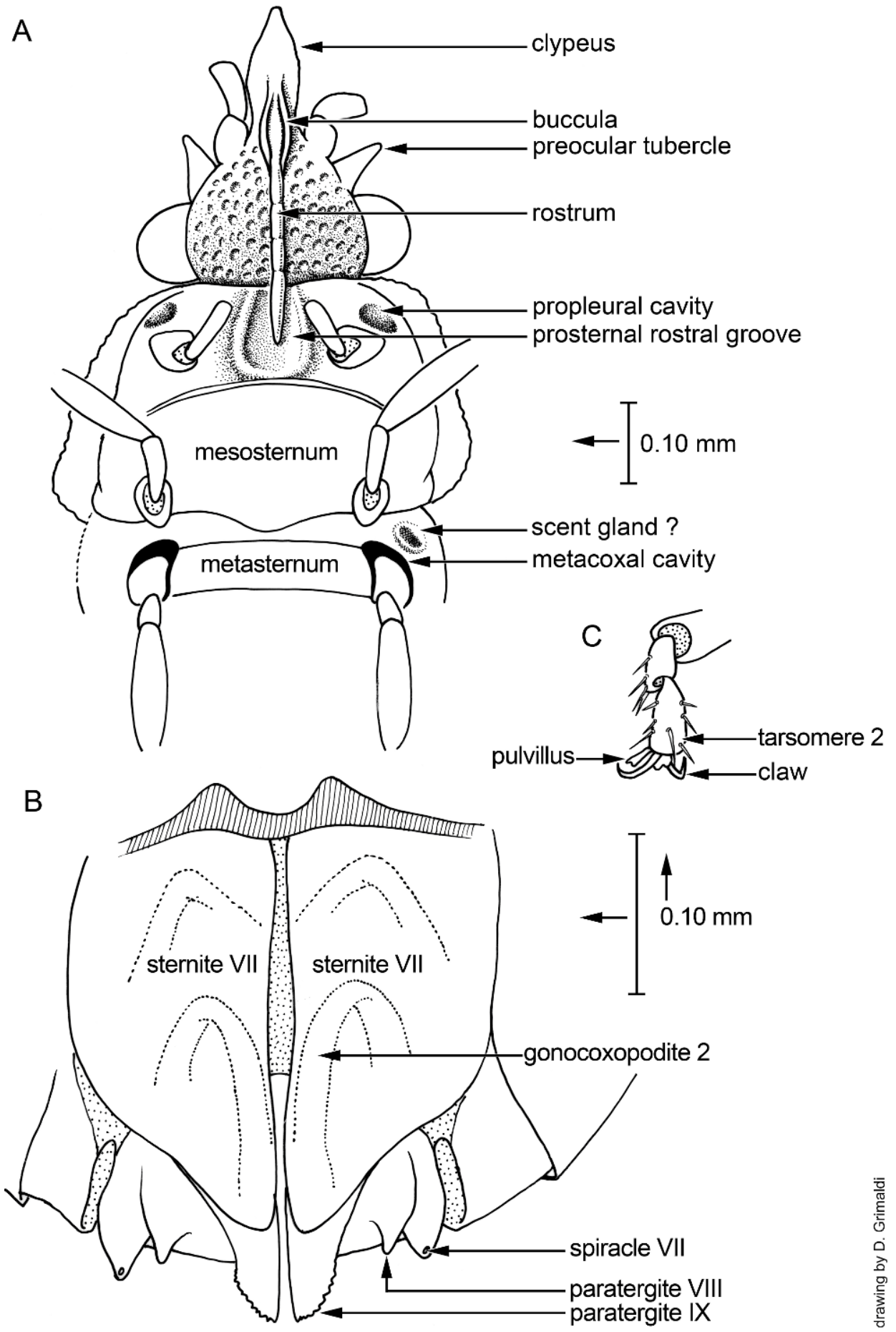

Fig. 3. Details of holotype of Cretopiesma suukyiae, new genus and species. A. Ventral view of head and thorax. B. Apex of abdomen (ventral view). C. Mesothoracic tarsus. 
4 fusiform, with dense, long setulae at apex. Antennal insertion between preocular tubercle and clypeus. Rostrum extended to level of fore coxae (segmentation obscure).

Thorax: Pronotum broad (length at middle $0.28 \mathrm{~mm}$, greatest width $0.52 \mathrm{~mm}$ ), explanate; trapezoidal in shape, with lateral margins diverging caudad, posterior margin slightly concave (vs. slightly convex or flat). Pronotum areolate over entire dorsal surface, with two large paramedial carinae extended full length of pronotum. Carinae tapered in thickness and slightly divergent caudad; anteriorly fused with thick transverse carina on anterior margin of pronotum. Pronotum with pair of callosities lateral to carinae and in slightly recessed areas. Mesoscutellum very large, $0.31 \mathrm{~mm}$ in length, $0.37 \mathrm{~mm}$ width; dorsal surface completely areolate, with apical margin broadly rounded. Posterior half of scutellum with paramedial pair of rounded depressions. All sternites smooth, not areolate or punctate. Prosternum with very broad rostral groove; no mesosternal groove. Propleural cavities present, just anterior to fore coxae. Metasternum very broad; no scent gland channel present, but apparently with small ostiole (scent gland opening?) anterolateral to metacoxa. All coxae widely separated in each pair. Legs short, femur thickest podite; all podites devoid of spines, but femur and tibia covered with numerous, fine tubercles. Tarsi with two short tarsomeres, apical tarsomere slightly longer; pretarsal claws apparently simple, rather long; pulvilli large, slender, flat, slightly shorter than claws.

Wings: Hemelytra short (submacropterous form?), apices extend to apex of abdomen but not beyond; length $0.76 \mathrm{~mm}$, greatest width $0.28 \mathrm{~mm}$. Apex of hemelytron broadly rounded, not narrowed. Corium occupies approximately half the hemelytral surface; entire corium areolate, except veins. Veins thickened, heavily sclerotized. Vein $\mathrm{C}$ short, occupies $2 / 3$ basal half of hemelytron. Sc very short, branches off main stem of $\mathrm{Cu}$, meets $\mathrm{C}$ (not $\mathrm{R}+\mathrm{M}$ ), length ca. $0.25 \times$ wing length. Two thick transverse veins present, one connecting apex of $\mathrm{Sc}$ and $\mathrm{Cu}$ (near apex of clavus); another a slightly $\mathrm{V}$-shaped crossvein near middle of wing connecting $\mathrm{C}$ and $\mathrm{Cu}$. Clavus narrow, apex very slender and acute, mem- brane areolate; distinct commissure between clavus and rest of corium. Membrane of hemelytra with fine reticulations, four faint longitudinal veins with apices evanescent and not meeting distal margin of wing. Membrane veins interpreted here as $\mathrm{R}, \mathrm{M}, \mathrm{Cu}$, and $\mathrm{PCu}$; latter two veins convergent but not actually intersecting. Hind wing unapparent or absent.

Abdomen: Flat, broad; length $0.85 \mathrm{~mm}$, width $0.55 \mathrm{~mm}$. Ventral trichobothria not apparent, or absent. Spiracles situated dorsally on paratergites II-V. Tergite VII with numerous small spicules. Pair of spiracles on segment VII situated on small tubercles. Paratergites VIII a pair of small lobes flanking paratergites IX, which are apicalmost appendages. Paratergites IX apparently flat, with outer margins finely dentate. Sternite VII divided, pair of gonocoxopodite 2 visible beneath sternite VII, $\cap$-shaped.

Material eXamined: Holotype (unique specimen), female, AMNH Bu958, from Kachin Province, northern Myanmar, near the town of Tanai in the Hukwang Valley. In the amber fossil collection, Division of Invertebrate Zoology, American Museum of Natural History.

ETYMology: Matronym in honor of Aung San Suu Kyi from Burma, the 1991 laureate of the Nobel Peace Prize. Ms. Suu Kyi has spent 18 years isolated in house confinement (from 1989-95, 2000-02, and 2003 to present) for her promotion of democracy in Myanmar. It is fitting that a Burmese species, seemingly delicate but which has beautifully endured for so long, be named in her honor.

\section{DISCUSSION}

On the surface, the many unique or highly unusual features of Cretopiesma listed in the generic diagnosis might suggest its placement in a family other than Piesmatidae. However, at least some of these features are plesiomorphic for the family and others autapomorphic. More importantly, features of Cretopiesma that are diagnostic for Piesmatidae are the following: head, thorax, and corium with the same, distinctive form of areolation (e.g., fig. 4A); a short, stout second antennomere (cf. figs. 2, 4C); pronotum explanate and with dorsal carinae; presence of propleural cavities (figs. 3, 

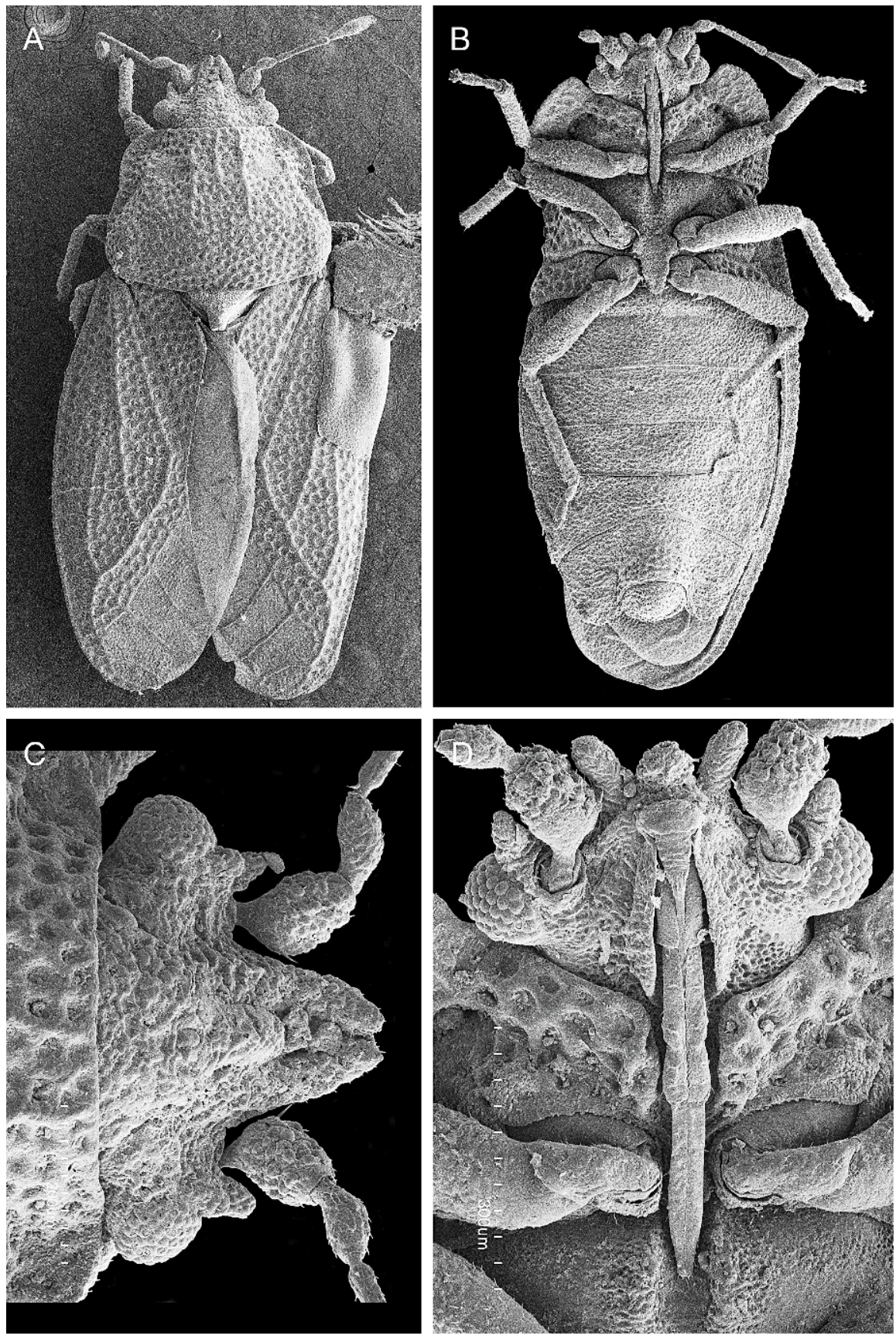

Fig. 4. Scanning electron micrographs of Piesma spp. (A, C: Arizona; B, D: South Africa). A. Habitus, dorsal view. B. Habitus, ventral view. C. Head and anterior pronotum, dorsal view. D. Head and anterior thorax, ventral view. 

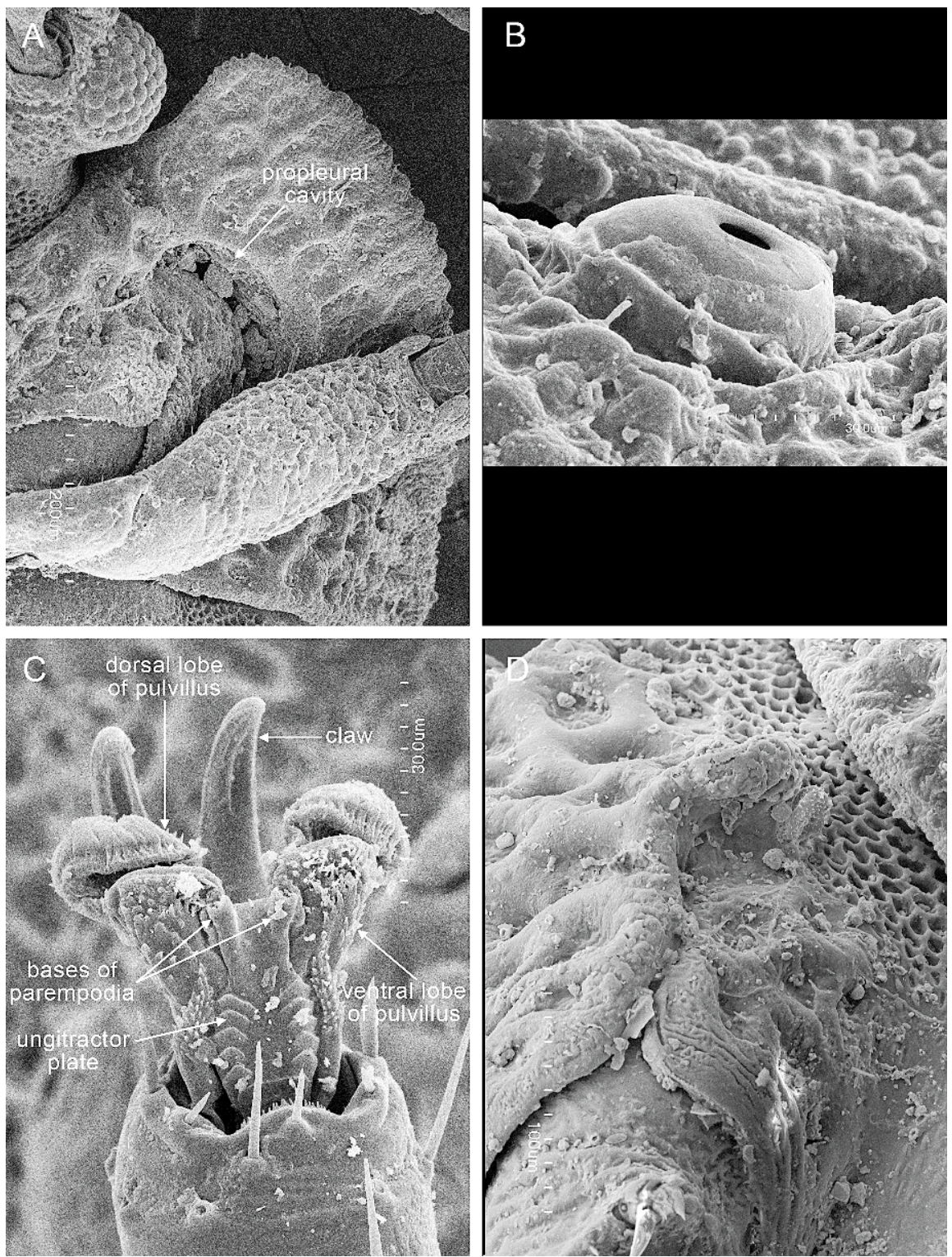

Fig. 5. Scanning electron micrographs of Piesma sp. (South Africa). A. Left anterior portion of thorax (ventral view), showing propleural cavity. B. Trichobothrial pad. C. Pretarsus, showing well-developed pulvilli. D. mesopleural fold near coxa.

5A); and the structure of the female terminalia, where sternum VII is entirely divided into hemisternites, the ovipositor lanceolate, and the second pair of gonocoxopodites are an inverted U (fig. 3). Further features of Cretopiesma that are consistent with Piesmatidae (though not exclusive to this family) are the small, flattened body; proportions of the four antennomeres; preocular tubercles large and protuberant; hemelytron with basal half coriaceous, apical half membranous with four light veins (fig. 2); two tarsomeres present, with pretarsus having a pair of large, leaflike pulvilli (fig. 1D). 


\section{Relationships within Piesmatidae}

An attempt was made to investigate relationships among living and fossil genera by expanding upon and revising those characters employed by Schaefer (1972, 1981). In addition, several new characters were included to accommodate the features found in the one Cretaceous (herein) and two Eocene (Nel et al., 2004; Popov, 2001) fossils. Twenty-three characters were identified and coded for cladistic analysis. In the following list apomorphies are described first (coded as 1 in the matrix: table 1), succeeded by brief notes on the distribution of the trait and its plesiomorphic condition. Outgroups included the basal pentatomomorphan family Aradidae.

\section{HEAD:}

1. Clypeus reduced, not projecting. This feature is found in all Recent piesmatid species and in the Tertiary fossils. Cretopiesma plesiomorphically has a strongly projecting clypeus similar to that of many Aradidae (cf. figs. 2, 6A).

2. Preocular tubercles bifid, with small secondary pair lateral to the large pair found in Recent and extinct species. This feature is autapomorphically present in Piesma (Parapiesma); all other species have the single large pair.

3. Rostrum short, apex extending no farther than the level of procoxae. Plesiomorphically, the rostrum extends well beyond this level, a condition found in the fossil genera Heissiana and Eopiesma, and in $P$. (Parapiesma) kolenatii (Fieber), P. pupula Puton, and P. tenellum Horvath.

4. "Jugal" lobes ${ }^{3}$ absent, which is a feature found in Cretopiesma. All other piesmatids have well-developed jugal lobes (figs. 4C, D).

5. "Jugal" lobes long, projecting well beyond the clypeus in adults, which is found in Piesma s.1. Plesiomorphically, the apices of the jugal lobes are at the same level as the apex of the clypeus.

\footnotetext{
${ }^{3}$ This is an adjectival form of the "juga" (extensions lateral to the clypeus) and should not be confused with the more widespread application of this term for the membranous lobe formed by the jugum in the posterior base of the insect wing.
}

TABLE 1

Data Matrix for Phylogenetic Analysis of Piesmatidae

(see text for description of characters)

\begin{tabular}{lc}
\hline \hline \multicolumn{1}{c}{ taxa } & characters \\
\hline & 11111111112222 \\
Piesma & 12345678901234567890123 \\
$($ Piesma $)$ & $10111110 \$ 11111111011111$ \\
$($ Parapiesma $)$ & 11111110211111111011111 \\
$($ Afropiesma $)$ & 10111110011111111011111 \\
Miespa & $10110000201101 ? 11011011$ \\
Mcateella & 10110000201111011211011 \\
Heissiana & $10010000101111 ? 1111 ? 011$ \\
Eopiesma & $10010001 ? 01 ? ?$ ? $0011 ? 0111$ \\
Cretopiesma & 00100110010000010000011 \\
Outgroup* & 00000000000000000000000 \\
\hline * The outgroup was generated from plesiomorphic states \\
inferred by comparison across basal pentatomorphs. \\
\$ subset polymorphism (=0/1)
\end{tabular}

6. Third antennomere very slender and significantly longer than second antennomere, which is a feature found in Piesma and Cretopiesma (figs. 2, 4B). In the plesiomorphic condition the third antennomere is barely longer or even shorter than antennomere 2, which is found in the austral and Tertiary fossil genera.

7. Position of head porrect (apomorphic) versus declivant, the apomorphic state occurring in Piesma and Cretopiesma.

\section{THORAX:}

8. Absence of pronotal callosities (or calli): this state is hypothesized to be apomorphic (i.e., a loss), since the presence of callosities is widespread in Heteroptera. This presumably occurs just in the fossil Eopiesma, but the structure can be difficult to discern even in amber fossils (and the bubble above the pronotum in the unique holotype [Nel et al., 2004: 46, fig. 1] might obscure this feature). Like all other features of Eopiesma that we scored, we relied on the observations by Nel et al. (2004).

9. Pronotum with short, median carina (e.g., fig. 4A): Plesiomorphically this structure is absent (0); apomorphically with small or faint carina (1), or with a welldeveloped, longer carina (2). This feature 

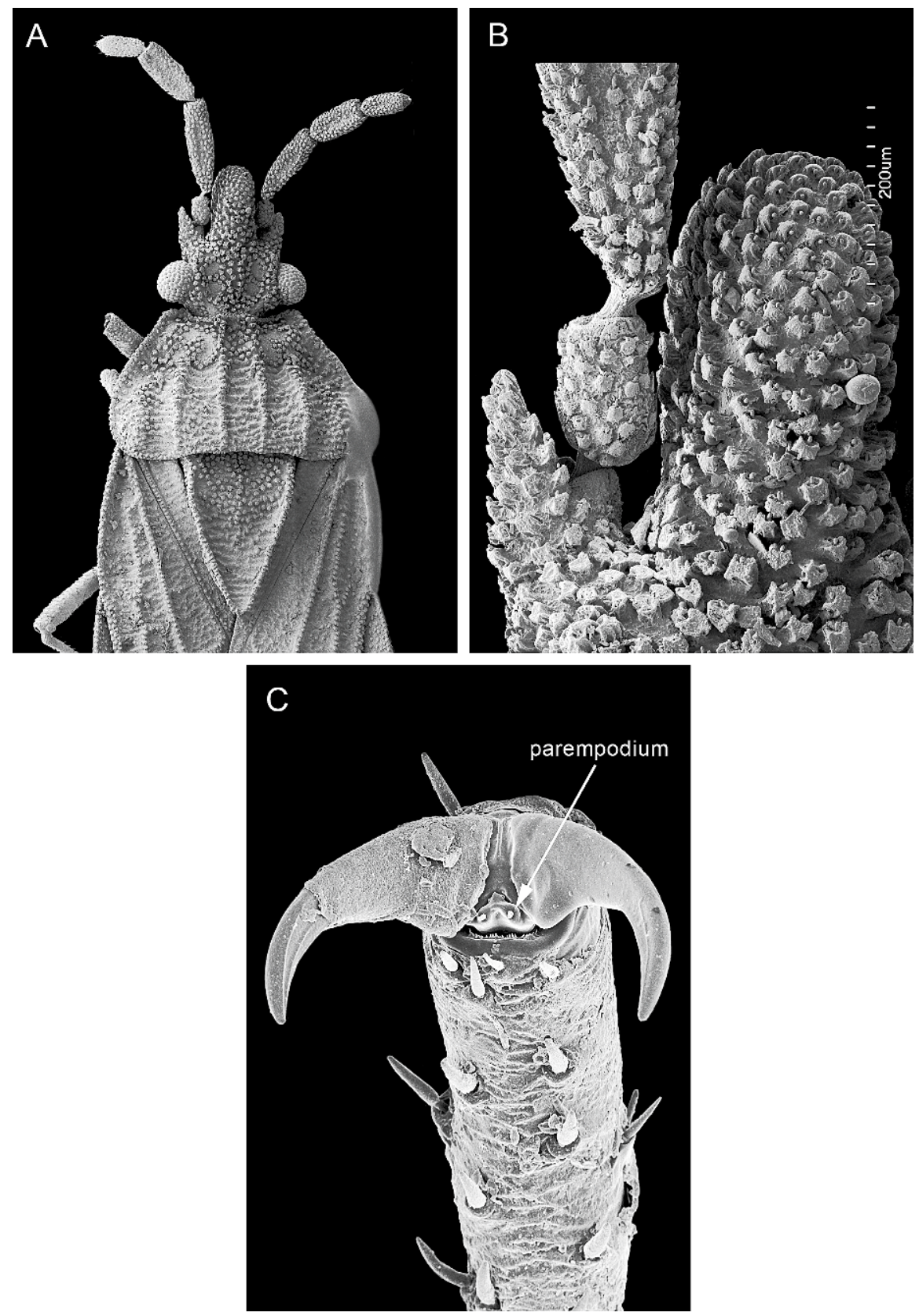

Fig. 6. Scanning electron micrographs of Aradus brasiliensis Usinger (Aradidae). A. Dorsal habitus, anterior half. B. Detail of clypeus, jugal lobe and antennal base (dorsal view). C. Detail of pretarsus (terminal view).

was coded as "?"' in the matrix for Eopiesma, even though this genus was reported to lack carinae. A bubble obscures the relevant area of the prono- tum in the unique type of Eopiesma, so if it is present and as cryptic as it is in Heissiana (personal obs.) then it would not be noticeable in Eopiesma. 
10. Pronotum with paired, paramedian carinae (usually incomplete [fig. 4A], but complete in Cretopiesma [fig. 2]). The absence of the paramedian carinae is interpreted as primitive. Note that the complete absence of pronotal carinae in Eopiesma is enigmatic as all piesmatids have some combination of carinaeeither paramedian carinae or a median carina (character 9). The bubble above the pronotum in the unique holotype of E. trimerus (Nel et al., 2004: 46, fig. 1) might obscure this feature.

11. Mesoscutellum small: it is uniformly and apomorphically small in Recent and Tertiary Piesmatidae (fig. 4A), generally half or less the clavus length. Cretopiesma plesiomorphically has a very large scutellum (widespread throughout Pentatomomorpha [fig. 6A]), which is longer than the clavus.

12. Pair of mesopleural tubercles present laterally (apomorphic). The absence of these tubercles is a notable plesiomorphy of Cretopiesma.

13. Mesosternum and prosternum with labial depressions (fig. 4D), a state apomorphic to that in which the labial depression occurs only on the prosternum (fig. 3).

14. Pleural lamina ("coxal lobes") are apomorphically present on all living piesmatids, as well as in the Eocene Heissiana, but absent in Cretopiesma.

15. Metathoracic scent gland channels present, and apomorphically in the form of a pair of narrow, transverse troughs (fig. 4B). These occur in all Recent genera except Mcateella (unknown for Miespa), and do not occur in the fossil genera in which this area is visible.

16. Tarsomere number reduced to two, which occurs in all genera except Eopiesma, which has three. Three tarsomeres is almost certainly the plesiomorphic state. Since Nel et al. (2004: 47, fig. 2) have photographs of the trimerous tarsi of Eopiesma, the condition is unambiguous for that genus.

17. Corium venation with what are presumed to be veins $\mathrm{R}+\mathrm{M}(\mathrm{Cu}$ in Heiss and Pericart, 1983) and $\mathrm{Cu}(\mathrm{Br}$, ibid.) meet in a vein that runs parallel and proximal to the distal edge of the corium. Corium venation is very conservative in piesmatids, the exception being Cretopiesma. In that genus, and apparently the plesiomorphic condition, these veins extend directly to the proximal edge of the corium, with nebulous extensions into the membrane (fig. 2).

18. Hemelytral membrane veins reduced (Eopiesma and Heissiana to three veins: state 1) or absent (Mcateella: state 2). All other piesmatids have four nebulous veins in the membrane.

19. Coxal bases are apomorphically close to each other in each pair, generally separated by a distance no greater than the diameter of the coxal base (fig. 4B). This is apomorphically found in all piesmatids including Heissiana, but plesiomorphically not in Cretopiesma, which has the coxae of each segment very widely separated by a distance of $3-4 \times$ the coxal diameter (fig. 3). Widely separated coxae are found in some basal pentatomomorphs, such as Aradidae.

\section{ABDOMEN:}

20. Abdominal spiracles $2-5$ or 2-6 are dorsally situated apomorphically. Plesiomorphically spiracles $2-5$ are situated dorsally, and pair 6 ventrally, as in Eopiesma, Cretopiesma, and Piesma s.1.

21. Trichobothria are present as a single pair laterally on sternites V and VI (fig. 5B), but plesiomorphically absent in Heissiana, Miespa, Mcateella, and Cretopies$m a$. The ground-plan condition of the Pentatomomorpha would seem to be the presence of abdominal trichobothria, but this pertains to the Trichophora (i.e., all pentatomomorphs except Aradoidea).

22. Female sternum VII divided medially into lateral hemisternites. This notable apomorphy is found in all Recent Piesmatidae and in Cretopiesma (unknown for the other fossils), and probably supports monophyly of the family.

23. Second gonocoxopodites in an inverted$\mathrm{U}$ (i.e., $\cap$ ) configuration (fig. 3B). Like character 22, this feature may support monophyly of the family. 


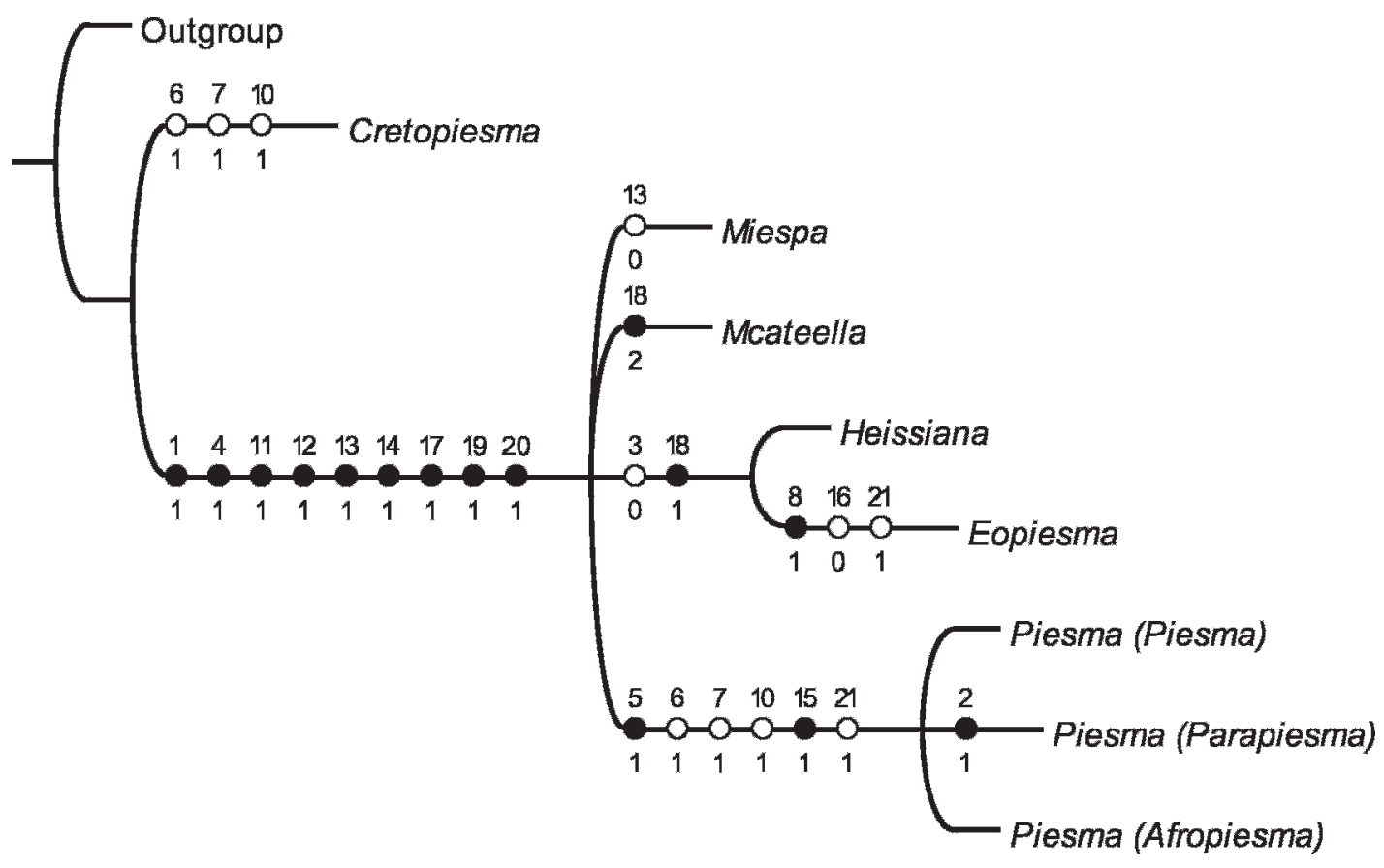

Fig. 7. Strict consensus tree (L 33, C.I. 72, R.I. 75) of four cladograms of Recent and extinct genera of Piesmatidae, based on the matrix in table 1. Characters on the cladogram are listed in the text. Open circles are homoplasious characters; solid circles are unambiguous synapomorphies.

The matrix is provided in table 1 . All characters were considered nonadditive and of equal weight. The matrix was analyzed using the $w h^{*}$; max* commands in NONA (Goloboff, 1997) and the resultant topologies visualized with WinClada (Nixon, 2002). The analysis revealed a single topology with 33 steps, a consistency index of 0.72 and retention index of 0.75 . There were four equally most parsimonious trees, with the consensus cladogram presented in fig. 7. This cladogram, and the meager diversity of the family, suggest that the recognition of higher groups within Piesmatidae is unwarranted. Popov (2001) established the tribe Heissianini for Mcateella, Miespa, and the Baltic amber genus Heissiana. As the cladistic analysis demonstrates, Heissianini is paraphyletic and should be retained for Heissiana and Eopiesma only. Interestingly, these two genera are approximately contemporaneous in the Eocene.

Also interesting is that the austral genera, Miespa and Mcateella, appear not to be sister taxa (contrary to Popov, 2001), but form a paraphyletic stem group to the living piesmatids and thus cast different light on the supposed gondwanan vicariance of these two genera. Instead, the piesmatids were likely widespread in the past and have dwindled in diversity, undergoing differential extinction across the Northern Hemisphere (perhaps at the Eocene-Oligocene transition), leaving Mcateella and Miespa isolated in the southern temperate regions of South America and Australia. Though Miespa and Mcateella are austral relicts in a modern bipolar distribution the family was likely widespread as recently as the Early Tertiary and long after the rifting of Gondwana. Paleontological data has revealed that many apparent Recent austral disjunctions were previously widespread (Grimaldi and Engel, 2005), a pattern to which piesmatids can be added.

\section{Phylogenetic Position of Piesmatidae}

As mentioned in the Introduction, identifying the living sister group of the Piesmatidae 
has been challenging. The earliest classifications placed Piesmatidae with the cimicomorphan family Tingidae or in various positions among the Lygaeoidea. Henry (1997) considered piesmatids as lygaeoids and included within the family the rare and unusual Psamminae.

While Cretopiesma is very likely a piesmatid, it is also quite aradoid in character, which is a grouping of the two families that was first proposed by Spinola (1852), though on a superficial basis. Similarities that Cretopiesma plesiomorphically shares with Aradoidea include the very large mesoscutellum; coxae widely separated in each pair; and the absence of trichobothria. They apomorphically share a long, jutting clypeus. It is interesting that the Burmese amber fauna also contains a remarkably primitive aradid, Archearadus burmensis Heiss and Grimaldi (2001, 2002), which possesses the plesiomorphic features of pseudopulvilli on the pretarsus, dimerous tarsi, and metapleural scent gland ostioles, but which in all other respects is a typical aradid. Indeed, primitive for aradids are a rostrum arising far from the clypeal apex, basally enclosed by bucculae and about as long as the head, and a prosternal furrow for reception of the rostrum-all features similarly possessed by Cretopiesma. Cretopiesma differs from all living and extinct aradids in several striking respects: 1 . It is far smaller than any known aradid; 2 . it has well developed pseudopulvilli (cf. figs. 1D, 3C, 5C, 6C), while most living aradids have lost these; 3 . the antennal structure and proportions are very similar to those of piesmatids, and are not stout and papillate as in aradids (fig. 6A); and, 4. the cuticular microsculpture of Cretopiesma is completely unlike that of aradids. Most aradids have a granular cuticle, which under SEM magnification (fig. 6B) reveals the granules to have a distinctive irregular to stellate form, with a small papilla recessed at the apex.

Despite these striking differences, one reviewer maintained that Cretopiesma was actually an aradid, and that the subordinate placement of Piesmatidae within Lygaeoidea in Henry's (1997) phylogeny precluded Piesmatidae from being closely related to Aradidae or being at the base of the Pentatomomorpha. In fact, there are several aspects of that paper that reveal that caution should be used in interpreting the proposed pentatomomorph relationships. One, the terminal taxa in the analysis were not exemplar species, but subfamilies and families, so terminal taxa were coded as ground plans. Secondly, several of the more inclusive synapomorphies proposed by Henry (1997) do not apply to the Piesmatidae, such as his characters 5-0, 20-1, 28-1, 47, and 48. Third, we re-analyzed the original matrix in Henry (1997) using NONA, and a strict consensus of the raw data (no weighting) produced a tree with 12 unresolved basal branches, seven of which were groupings of 2-7 terminals ( $\mathrm{L}=175$ steps based on 12 trees, $\mathrm{CI}=41, \mathrm{RI}=67)$. While the smaller groupings of taxa in this strict consensus tree and in Henry's preferred tree (his fig. 3) entirely coincided, the basal relationships were completely different. A strict consensus tree based on 11 ordered multistate characters (Henry [1997] mentioned there were nine, but there are actually 11 in the matrix) produced a tree in NONA of 190 steps (from 24 trees total), or CI $=38$ and $\mathrm{RI}=69$, which is shorter than the one in Henry (1997). The cladograms with ordered characters were largely similar, except for significant differences among basal lygaeoids - precisely the area of the tree where Piesmatidae supposedly fit. This similarity, however, is what one would expect by constraining character evolution, particularly when $20 \%$ of the characters are ordered. Fourth, for nine nodes and 38 steps, seven characters involved a loss from basal nodes (4, $5,19,32,35,46,47)$ and/or their re-appearance $(4,12)$. Interpreting the absence of features in such cases is ambiguous. In Henry's (1997) hypothesis, a piesmatid-psammine relationship (the "most well-supported grouping") was specifically based on the loss of ocelli, presence of "hemelytral punctures or areoles", twosegmented tarsi, loss of trichobothria on abdominal sternites IV and $\mathrm{V}$, very short second antennomere, and a "scutellar process". Reduction of the tarsus to two tarsomeres, as for all characters of loss, is difficult to homologize. Also, most adult macropterous piesmatids have ocelli, as well as trichobothria on sternum $\mathrm{V}$ (abdominal trichobothria are absent or very highly reduced in Miespa, Mcateella, and Cretopiesma). Furthermore, 
the cuticular microsculpture of psammines and piesmatids is distinctively different - the former has punctures and rugosities, the latter irregular areoles. Lastly, the position of the Psamminae in Henry (1997) is based partly on three characters that are inferred, and actually unknown, for this rare group (57-1: structure of egg eclosion fracture; 42-2: karyology; and 521: number of salivary gland lobes).

While we recognize the contributions brought to the confusing classification of Lygaeoidea by Henry (1997), we don't believe that on the basis of this study one could dismiss the possibility of a close relationship between Piesmatidae and Aradoidea, as Cretopiesma suggests.

\section{Geological History of Pentatomomorpha}

The confusing phylogenetic position of Piesmatidae highlights the difficulty of placing some higher Panheteroptera, even with full suites of data using modern species. Thus, the consistent lack of critical details in fossils, particularly compressions, seriously compromises the placement of fossils. This must be kept in mind with any consideration of the geological history of Pentatomorpha.

Abundant compression fossils from the Mesozoic have been ascribed to the Pentatomomorpha, and to modern superfamilies and families thereof (e.g., Popov, 1968, 1980, 1986, 1990; Popov and Pinto, 2000). In contrast, the record of pentatomomorphs in Cretaceous ambers is exceedingly sparse, while modern superfamilies of Cimicomorpha (e.g., Tingoidea) are fairly diverse in Cretaceous amber (e.g., Golub and Popov, 2000, 2003; Perrichot et al., 2006). Indeed, the only documented Cretaceous amber Pentatomomorpha are the aforementioned aradid $A$. burmensis and Cretopiesma suukyiae, both in Burmese amber and both significantly plesiomorphic. While it is reasonable to assume that Aradoidea and Piesmatidae originated in the Early Cretaceous, ca. 140-120 Ma, definitive Trichophora are not known until the Tertiary. Trichophorans (as are commonly defined and understood based on modern representatives) no doubt were probably present during the Late Cretaceous, and Pentatomomorpha probably originated in the Late Jurassic, since definitive cimicomorphas do occur as compressions in such deposits (e.g., Zhang et al., 2005). However, the Jurassic and Early Cretaceous taxa that are assigned to modern trichophoran superfamilies may actually be stem-group trichophorans or pentatomomorphans. The discovery of additional pentatomomorphans in Cretaceous ambers will contribute significant information on the age and phylogeny of these bugs.

\section{ACKNOWLEDGMENTS}

We are grateful for the authoritative commentary on the manuscript provided by Ernst Heiss (Tiroler Landesmuseum, Innsbruck), Carl Schaefer (University of Connecticut, Storrs), and an anonymous reviewer. We are further grateful to Wolfgang Weitschat, who kindly loaned specimens of Heissiana; to Tam Nguyen (AMNH), who assisted with preparation of the plates; and to the U. S. National Science Foundation (grants DEB-0542726 to DG and DEB-0542909 to MSE), which provided funding. This is contribution 3481 of the Division of Entomology, Natural History Museum, University of Kansas.

\section{REFERENCES}

Amyot, C.J.B., and J.G. Audinet-Serville. 1843. Histoire naturelle des insectes: Hèmiptères. Paris: Fain et Thunot, 1xxvi $+675+6$ pp.

Cruickshank, R.D., and K. Ko. 2003. Geology of an amber locality in the Hukawng Valley, northern Myanmar. Journal of Asian Earth Sciences 21(5): 441-455.

Dohrn, F.A. 1859. Catalogus Hemipterorum. Stettin: Entomologischen Verein zu Stettin, iv $+112 \mathrm{pp}$.

Drake, C.J., and N.T. Davis. 1958. The morphology and systematics of the Piesmatidae (Hemiptera), with keys to the world genera and American species. Annals of the Entomological Society of America 51: 567-581.

Goloboff, P.A. 1997. NoName (NONA), version 2.0. Program and documentation. Tucumán: Fundación y Instituto Miguel Lillo.

Golub, V.B., and Y.A. Popov. 2000. A remarkable fossil lace bug from Upper Cretaceous New Jersey amber (Heteroptera: Tingoidea, Vianaididae), with some phylogenetic commentary. In D. Grimaldi (editor), Studies on fossils in amber, with particular reference to the 
Cretaceous of New Jersey: 231-239. Leiden: Backhuys Publishers, viii +498 pp.

Golub, V.B., and Y.A. Popov. 2003. The new fossil genus of Vianaididae (Heteroptera: Tingoidea) from the Cretaceous amber of New Jersey; evolution of the family in the Late Cretaceous. Acta Zoologica Cracoviensia 46(supplement): 109-116.

Grimaldi, D., and M.S. Engel. 2005. Evolution of the Insects. Cambridge: Cambridge University Press, $\mathrm{xV}+755 \mathrm{pp}$.

Grimaldi, D.A., M.S. Engel, and P.C. Nascimbene. 2002. Fossiliferous Cretaceous amber from Myanmar (Burma): its rediscovery, biotic diversity, and paleontological significance. American Museum Novitates 3361: 1-72.

Heiss, E., and D. Grimaldi. 2001. Archearadus burmensis gen. n., sp. n., a remarkable Mesozoic Aradidae in Burmese amber (Heteroptera, Aradidae). Carolinea 59: 99-102.

Heiss, E., and D. Grimaldi. 2002. The first known female of Archearadus burmensis Heiss and Grimaldi, 2001, in Cretaceous Burmese amber (Heteroptera: Aradidae). Zeitschrift der Arbeitsgemeinschaft Österreichischer Entomologen 54: 55-59.

Heiss, E., and J. Péricart. 1983. Revision of Palaearctic Piesmatidae (Heteroptera). Mitteilungen der Münchner Entomologischen Gesellschaft 73: 61-171.

Heiss, E., and J. Péricart. 1997. Revised taxonomic status of some Old World Piesmatidae (Heteroptera). Zeitschrift der Arbeitsgemeinschaft Österreicheisches Entomologen 49: 119-120.

Heiss, E., and Y. Popov. 2002. Reconsideration of the systematic position of Thaicorinae with notes on fossil and extant Thaumastocoridae (Hemiptera: Heteroptera). Polskie Pismo Entomologiczne 71(3): 247-259.

Henry, T.J. 1997. Phylogenetic analysis of family groups within the infraorder Pentatomomorpha (Hemiptera: Heteroptera), with emphasis on the Lygaeoidea. Annals of the Entomological Society of America 90(3): 275-301.

Kormilev, N.A. 1969. Thaicorinae, n. subfam. from Thailand (Hemiptera: Heteroptera: Piesmatidae). Pacific Insects 11: 645-648.

Laporte, F.L., de. 1833. Essai d'une classification systématique de l'order des Hémiptères (Hémiptères-Héteroptères, Latr.). Magasin de Zoologie 1: 1-88 [and supplement].

Lepeletier de Saint-Fargeau, A.L.M., and J.G. Audinet-Serville. 1825. [Sections]. In G.A. Olivier (editor), Encyclopédie méthodique, ou par ordre de matières: histoire naturelle [vol. 10, part 1] Insectes. Paris: Agasee, 344 pp.
Leston, D., J.G. Pendergrast, and T.R.E. Southwood. 1954. Classification of the terrestrial Heteroptera (Geocorisae). Nature 174: 91.

Narisu 2000. Ash-gray leaf bugs (Piesmatidae). In C.W. Schaefer and A.R. Panizzi (editors), Heteroptera of economic importance: 265270. Boca Raton, FL: CRC Press, 828 pp.

Nascimbene, P.C., and H. Silverstein. 2000. The preparation of fragile Cretaceous ambers for conservation and study of organismal inclusions. In D. Grimaldi (editor), Studies on fossils in amber, with particular reference to the Cretaceous of New Jersey: 93-102. Leiden: Backhuys Publishers, viii +498 pp.

Nel, A., A. Waller, and G. De Ploëg. 2004. The oldest fossil piesmatid bug in the lowermost Eocene amber of the Paris Basin (Heteroptera: Lygaeoidea: Piesmatidae). Geologica Acta 2: 45-50.

Nixon, K.C. 2002. WinClada, version 1.00.08. Program and documentation. Ithaca, NY: Cornell University.

Péricart, J. 1974. Subdivision du genre Piesma (Hem. Piesmatidae) et remarques diverses. Annales de la Société Entomologique de France 10(1): 51-58.

Perrichot, V.A. Nel, E. Guilbert, and D. Néradeau. Fossil Tingoidea (Heteroptera: Cimicomorpha) from French Cretaceous amber, including Tingidae and a new family, Ebboidae. Zootaxa 1203: 57-68.

Popov, Y.A. 1968. True bugs of the Jurassic fauna of Karatau (Heteroptera). In B.B. Rohdendorf (editor), Jurassic insects from Karatau: 99-113. Moscow: Nauka Press, 252 pp. [in Russian]

Popov, Y.A. 1980. Superorder Cimicidea Laicharting 1781. Trudy Paleontologischeskogo Instituta 175: 58-69. [in Russian]

Popov, Y.A. 1986. Peloridiina (= Coleorrhyncha) et Cimicina (= Heteroptera). Trudy Sovmestnaya Sovestko Mongol'skaya Paleontologicheskaya Ekspeditsiya 28: 50-83. [in Russian]

Popov, Y.A. 1990. Bugs: Cimicina. Trudy Paleontologicheskogo Instituta 239: 20-39. [in Russian]

Popov, Y.A. 2001. Fossil piesmatids from Baltic amber (Heteroptera: Pentatomomorpha, Piesmatidae). Mitteilungen aus dem GeologichPaläontologiches Institut der Universität Hamburg 85: 211-220.

Popov, Y.A., and I.D. Pinto. 2000. On some Mesozoic burrower bugs (Heteroptera: Cydnidae). Paleontological Journal 34(supplement 3): 298-302.

Schaefer, C.W. 1972. A cladistic analysis of the Piesmatinae (Hemiptera-Heteroptera: Piesmatidae). Annals of the Entomological Society of America 65: 1258-1261. 
Schaefer, C.W. 1981. Improved cladistic analysis of the Piesmatidae and consideration of known host plants. Annals of the Entomological Society of America 74: 536-539.

Spinola, M. 1852. Tavola sinottica dei generi spettanti alla classe degli insetti artroidignati, Hemiptera, Linn. Latr. - Rhyngota, Fab. Rhyncota, Burm. Memorie di Matemática e di Física della Società Italiana delle Scienze, Modena 25(1): 43-178.

Štys, P. 1967. Monograph of Malcinae, with reconsideration of morphology and phylogeny of related groups (Heteroptera, Malcidae). Acta Entomologica Musei Nationalis Pragae 37: $351-516$

Tullgren, A. 1918. Zur Morphologie und Systematik der Hemipteren. Entomologisk Tidskrift 39: 113-132.

Zhang, J.-F., V.B. Golub, Y.A. Popov, and D.E. Shcherbakov. 2005. Ignotingidae fam. nov. (Insecta: Heteroptera: Tingoidea), the earliest lace bugs from the Upper Mesozoic of eastern China. Cretaceous Research 26(5): 783 792. 


Complete lists of all issues of the Novitates and the Bulletin are available at World Wide Web site http://library.amnh.org/pubs. Inquire about ordering printed copies via e-mail from scipubs@amnh.org or via standard mail from: American Museum of Natural History, Library-Scientific Publications, Central Park West at 79th St., New York, NY 10024. TEL: (212) 769-5545. FAX: (212) 769-5009.

(2) This paper meets the requirements of ANSI/NISO Z39.48-1992 (Permanence of Paper). 